\title{
Lipid damage is the best marker of oxidative injury during the cardiac remodeling process induced by tobacco smoke
}

\author{
Maria Angélica Martins Lourenço ${ }^{1}$, Mariana Gobbo Braz², Aline Garcia Aun², Bruna Letícia Buzati Pereira1, \\ Fábio Henrique Fernandes³ , Elisa Moya Kazmarek', Tatiana Fernanda Bachiega', Silmeia Garcia Zanati', \\ Paula Schmidt Azevedo ${ }^{1}$, Bertha Furlan Polegato ${ }^{1}$, Ana Angélica Henrique Fernandes ${ }^{4}$, \\ Sergio Alberto Rupp de Paiva ${ }^{1}$, Leonardo Antonio Mamede Zornoff ${ }^{1}$ and Marcos Ferreira Minicucci ${ }^{1,5^{*}}$
}

\begin{abstract}
Background: Oxidative stress is one potential mechanism that explain the direct effects of smoking on cardiac remodeling process. However, no study has compared different myocardial products of macromolecule oxidation after tobacco smoke exposure. Thus, the aim of this study was to investigate the lipid hydroperoxide (LH) levels, protein carbonyl concentrations and DNA damage in cardiac tissue of rats exposed to tobacco smoke.

Methods: Male Wistar rats were divided into two groups: group $C$ (control, $n=14$ ) composed of animals not exposed to cigarette smoke; group ETS (exposed to tobacco smoke, $n=14$ ) composed by animals exposed to cigarette smoke. The animals were exposed to 2 month of ETS and morphological, biochemical and functional analyses were performed.
\end{abstract}

Results: Cardiac cotinine levels were elevated in the ETS group. In addition, the myocyte cross-sectional area was higher in the ETS group. $\left(C=266.6 \pm 23.2 \mu \mathrm{m}^{2}\right.$ and ETS $\left.=347.5 \pm 15.1 \mu \mathrm{m}^{2}, p<0.001\right)$. Cardiac LH was higher in the ETS group than in group $C(C=196.4 \pm 51.5 \mathrm{nmol} / \mathrm{g}$ and $\mathrm{ETS}=331.9 \pm 52.9 \mathrm{nmol} / \mathrm{g}, \mathrm{p}<0.001)$. However, there were no between-group differences in cardiac protein carbonyl concentration or DNA damage.

Conclusions: Therefore, our results suggest that, in this model, lipid damage is a good marker of oxidative damage during the cardiac remodeling process induced by 2 months of exposure to tobacco smoke.

Keywords: Comet assay, DNA damage, Protein carbonyl groups, Cigarette smoke

\section{Background}

Tobacco smoke is one of the major risk factors and is the leading cause of preventable death for cardiovascular disease [1]. In addition to the well-known effects of cigarette smoke on vascular systems, the direct effects of smoking on cardiac remodeling have been studied [2-7]. Using an animal model, other have found that exposure to tobacco

\footnotetext{
* Correspondence: minicucci@fmb.unesp.br

'Internal Medicine Department, Botucatu Medical School, UNESP - São Paulo State University, Botucatu, Brazil

${ }^{5}$ Departamento de Clínica Médica, Faculdade de Medicina de Botucatu,

Rubião Júnior s/n, Botucatu, SP CEP: 18618-000, Brazil

Full list of author information is available at the end of the article
}

smoke (ETS) induces enlargement of the ventricular chambers and is associated with myocardial hypertrophy, as well as cardiac dysfunction [2-9]. Potential mechanisms for these alterations include hemodynamic and neurohormonal changes, mitogen-activated protein kinase activation, cardiac lipotoxicity and oxidative stress [5-7, 10-13].

Oxidative stress occurs when there is an imbalance between reactive oxygen species (ROS) production and antioxidant systems. Tobacco smoke has more than 4000 chemical compounds and $10^{15}$ to $10^{17}$ free radicals that cause tissue inflammation and ROS production [14]. However, the importance of ROS is not restricted to oxidative damage. In nanomolar concentrations, ROS 
play an important role in signal transduction pathways and in the modulation of transcription factors $[15,16]$. There are different sources of ROS, including mitochondrial electron transport, the cytochrome P450 system and the nicotinamide adenine dinucleotide phosphate $(\mathrm{NADPH})$ oxidase system $[15,16]$. We have previously shown that exposure of rats to tobacco smoke for two months increases myocardial NADPH activity, decreased the levels of antioxidant enzymes and increased cardiac lipid hydroperoxide levels [5].

Oxidative stress can be measured by different products derived by damage to proteins, lipids and DNA. Of note, clinical and experimental studies showed different results regarding biomarkers of oxidative damage. 8-hydroxyguanine, a biomarker of oxidative DNA damage was increased in human leukocytes, urine and lung tissue of smokers compared to nonsmokers [17-19]. However, other clinical and experimental studies showed no difference in DNA damage, assessed by the comet assay, in peripheral blood of human or rats exposed to tobacco smoke [20-22]. Likewise, plasma protein carbonyl concentration, a marker of protein oxidative damage, was increased in heavy smokers in some but not all studies [19, 23].

The different concentrations of these by-products of macromolecule oxidation could be due to the time of their measurement, tissue specificity or the nature of the ROS $[24,25]$. To the best of our knowledge, no study has compared different myocardial products of macromolecule oxidation after tobacco smoke exposure. We decided to study these products following 2 months of ETS, because this time is sufficient for the development of alterations in cardiac morphology and function. Since others have shown that 2 months of ETS exposure is associated with change in ventricular function and structure, the aim of the study was to determine the cardiac levels of lipid hydroperoxide, protein carbonyl concentration and DNA damage in rats exposed to tobacco smoke.

\section{Methods}

All experiments and procedures were performed in accordance with the National Institute of Health Guide for the Care and Use of Laboratory Animals and were approved by the Animal Ethics Committee of Botucatu Medical School (1116-2015).

Male Wistar rats weighing $200 \mathrm{~g}$ to $250 \mathrm{~g}$ were purchased from the Laboratory Animal Center of Botucatu Medical School. The rats were divided into 2 groups: group $C$ (control, $n=14$ ) composed by animals not exposed to cigarette smoke; group ETS (exposed to tobacco smoke, $\mathrm{n}=14$ ) composed by animals exposed to cigarette smoke. Food and water were supplied ad libitum. The animals were observed during 2 months, during which morphological, biochemical and functional analyses were performed. The rats were sacrificed with thiopental $(80 \mathrm{mg} / \mathrm{kg}$, IP), after which blood samples and heart were collected.

\section{Exposure to tobacco smoke}

The ETS rats were exposed to cigarette smoke in a chamber (dimensions $95 \times 80 \times 65 \mathrm{~cm}$ ) connected to a smoking device constructed based on a model published by Wang et al. and adapted by Paiva et al. [8, 26]. During the first week, the number of cigarettes was gradually increased from 5 to 10 cigarettes delivered in a $30 \mathrm{~min}$ period, administered twice each afternoon. Subsequently, 10 cigarettes were used in each smoking trial, repeated four times/day, twice in the morning and twice in the afternoon. The cigarette composition per unit is: $0.8 \mathrm{mg}$ of nicotine; $10 \mathrm{mg}$ of tar; and $8 \mathrm{mg}$ of carbon monoxide. In previous studies, we analyzed carboxyhemoglobin level in smoking rats. Given the corresponding carboxyhemoglobin levels, this protocol is similar to 3-4 pack/ day in a human. On the other hand, this protocol did not result in hypoxia [2].

\section{Isolated heart study: langendorff preparation}

After 2 months of exposure, six animals from each group were anesthetized with thiopental $(80 \mathrm{mg} / \mathrm{kg}$, IP) and received unfractionated heparin (2000 I.U., IP). After sternotomy, the rats were artificially ventilated, and the ascending aorta was dissected and cannulated. Retrograde perfusion was initiated with a modified Krebs-Henseleit solution, constantly gassed with a mixture of $95 \% \mathrm{O}_{2}$ and $5 \% \mathrm{CO}_{2}$, and a perfusion pressure of $75 \mathrm{mmHg}$ [27]. We performed the aorta cannulation with the heart in situ. With this procedure, we reduce the ischemic time. Only after aorta cannulation, and retrograde perfusion initiation we removed the heart. The heart was removed and transferred to an isolated heart perfusion apparatus (size 3, type 830, Hugo Sachs Elektronik - March-Hugstetten, Germany). A balloon was inserted in the left ventricular cavity, and the volume inside the balloon was modified to obtain a diastolic pressure of zero at $25 \mathrm{mmHg}$. We registered the diastolic and systolic pressures, the maximum left ventricular pressure decrease rate $(-\mathrm{dP} / \mathrm{dt})$ and the maximum left ventricular pressure development rate $(+\mathrm{dP} / \mathrm{dt})$. Systolic function was evaluated by $+\mathrm{dP} / \mathrm{dt}$, and diastolic function by $-\mathrm{dP} / \mathrm{dt}$. Developed pressure was also obtained.

The hearts that were submitted to the isolated heart study were not utilized for any other analysis as retrograde perfusion can interfere with subsequent biochemical analysis. 


\section{Morphometric analysis}

The right and left ventricles (including the interventricular septum) were dissected and separated. Transverse sections of the LV were fixed in $10 \%$ buffered formalin and embedded in paraffin. Five-micron-thick sections were stained with hematoxylin and eosin (HE). The myocyte cross-sectional area was determined for a minimum of 50 myocytes per HE-stained cross section. The measurements were obtained from digitized images $(\times 400$ magnification) collected using a video camera attached to a Leica microscope and computerized image analysis software (Image-Pro Plus 3.0, Media Cybernetics; Silver Spring, MD). The cells selected for analysis were transversely cut with the nucleus clearly identified in the center of the myocyte [5].

\section{Cardiac lipid hydroperoxide and protein carbonyl concentrations}

Two hundred-milligram samples of the left ventricle were homogenized in $5 \mathrm{~mL} 0.1 \mathrm{M}$ cold sodium phosphate buffer, $\mathrm{pH}$ 7.4, containing $1 \mathrm{mM}$ ethylenediaminetetraacetic acid (EDTA). Lipid hydroperoxide (LH) was measured through the hydroperoxide-mediated oxidation of $\mathrm{Fe}^{2+}$ as previously published [28-30]. The spectrophotometric determinations were performed in a Pharmacia Biotech spectrophotometer with a temperature-controlled cuvette chamber (UV/visible Ultrospec 5000 with Swift II Applications software connected to computer system control, 974,213, Cambridge, England, UK). All reagents were from Sigma (St. Louis, Missouri, USA) [28-30].

Protein carbonyl was analyzed through reaction with dinitrophenylhydrazine and formation of a Schiff base, according to the method described by Reznick and Packer [31]. The level of protein carbonyl was quantified spectrophotometrically at $360 \mathrm{~nm}$ using an extinction coefficient of 22,000 $\mathrm{M}^{-1} \mathrm{~cm}^{-1}$.

\section{DNA damage evaluation}

The Comet assay detects DNA damage at the individual cell level. Therefore, cardiomyocytes from LV fragments were isolated as described by Pool-Zobel et al. [32]. Suspensions of $2-6 \times 10^{6}$ cells were obtained per fragment. The cell viability was evaluated by the FDA/EtBr assay according to Strauss [33]. Briefly, a fresh staining solution was prepared containing $30 \mu \mathrm{L} F \mathrm{FD}$ in acetone $(5 \mathrm{mg} /$ $\mathrm{mL}), 200 \mu \mathrm{L} \mathrm{EtBr}$ in DPBS $(200 \mu \mathrm{g} / \mathrm{mL})$, and $4.8 \mathrm{~mL}$ DPBS. Then, $25 \mu \mathrm{L}$ from staining solution was mixed with $25 \mu \mathrm{L}$ of cardiomyocyte suspension, spread onto a slide, and covered with a coverslip. Green-fluorescent color indicated viable cardiomyocyte, whereas red-stained nuclei indicated dead cardiomyocytes. At least 200 cells were counted per sample.

The alkaline Comet assay measures single and double strand breaks, labile sites (SBs) and apurinic/apyrimidinic (AP) sites. DNA damage, including SBs, AP sites, oxidased pyrimidines (endonuclease III-sensitive sites), and altered purines [sites sensitive to formamidopyrimidine glycosylase (FPG)], was detected by the alkaline comet assay modified with the lesion-specific enzymes, FPG and endo III [34]. All procedures were conducted in the dark to minimize spurious sources of DNA damage. Briefly, $15 \mu \mathrm{L}$ of the cardiomyocyte suspensions were embedded into $0.5 \%$ low-melting point agarose (Sigma) and spread on agarose precoated microscope slides. Six slides were prepared for each sample. Slides were immersed overnight in freshly prepared cold lysing solution $(2.5 \mathrm{M} \mathrm{NaCl}, 100 \mathrm{mM}$ EDTA, $10 \mathrm{mM}$ Tris, $1 \%$ sodium salt $\mathrm{N}$-Lauryl sarcosine, $\mathrm{pH} 10.0$, with $1 \%$ Triton $\mathrm{X}-100$ and $10 \%$ DMSO added fresh) at $4{ }^{\circ} \mathrm{C}$. After lysing, the slides were washed three times in enzyme buffer and then two slides for each treatment were incubated at $37^{\circ} \mathrm{C}$ for $45 \mathrm{~min}$ with $100 \mu \mathrm{L}$ of endo III (1:1000) or $100 \mu \mathrm{L}$ of FPG (1:1000) or with enzyme buffer only. Endo III recognizes oxidized pyrimidines, while FPG identifies oxidized purines, especially 8-oxo-guanine. Enzyme buffer by itself was used to identify SBs. Subsequently, the cells were exposed to alkali buffer (1 mM EDTA and $300 \mathrm{mM} \mathrm{NaOH}$, $\mathrm{pH} \cong 13.4$ ), at $4{ }^{\circ} \mathrm{C}$, for $40 \mathrm{~min}$ to allow DNA unwinding and expression of alkali-labile sites. Electrophoresis was

Table 1 Morphological and Isolated heart study data

\begin{tabular}{llll}
\hline & $\begin{array}{l}\text { C Group } \\
n=8\end{array}$ & $\begin{array}{l}\text { ETS Group } \\
n=8\end{array}$ & $P$ value \\
\hline LWW/BW (mg/g) & $1.94 \pm 0.25$ & $2.07 \pm 0.16$ & 0.053 \\
RWW/BW (mg/g) & $0.48(0.43-0.55)$ & $0.54(0.45-0.96)$ & 0.328 \\
Lung weight/BW & $3.97(3.85-4.07)$ & $5.13(4.82-5.54)$ & $<0.001$ \\
Liver weight/BW & $31.1 \pm 3.2$ & $30.1 \pm 3.2$ & 0.543 \\
-dP/dt (mmHg) & $1896 \pm 161$ & $1958 \pm 129$ & 0.476 \\
+dP/dt $(\mathrm{mmHg})^{a}$ & $2521 \pm 290$ & $2563 \pm 190$ & 0.774 \\
Developed pressure $(\mathrm{mmHg})^{a}$ & $104.6 \pm 6.8$ & $108.3 \pm 10.5$ & 0.488 \\
\hline
\end{tabular}

$C$ control animals, ETS animals exposed to tobacco smoke, $B W$ body weight, $L V W$ left ventricular weight, $R V W$ right ventricular weight, $-d P / d t$ the maximum left ventricular pressure decrease rate, $+d P / d t$ the maximum left ventricular pressure development rate

Data are expressed as the mean \pm SD or medians (including the lower quartile and upper quartile)

a sample size $n=6$ for $C$ group and ETS group 

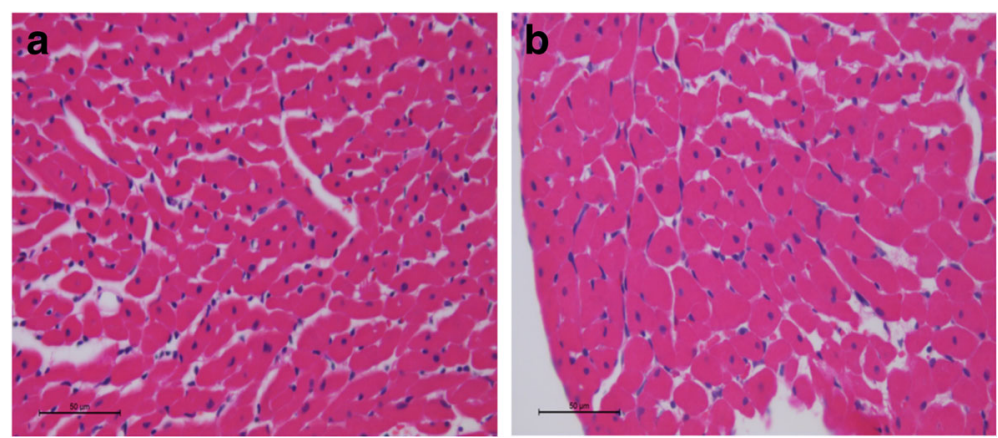

Fig. 1 Myocyte cross-sectional area (CSA) a. C group. b Exposed to Tobacco Smoke group. CSA was higher in ETS group compared to C group

conducted in the same solution at $4{ }^{\circ} \mathrm{C}$, for $30 \mathrm{~min}$, at $25 \mathrm{~V}$ $(1 \mathrm{v} / \mathrm{cm})$ and $300 \mathrm{~mA}$. After electrophoresis, the slides were neutralized (0.4 M Tris, $\mathrm{pH}$ 7.5), stained with $40 \mu \mathrm{L}$ EtBr $(20 \mu \mathrm{g} / \mathrm{mL})$, and analyzed by fluorescence microscopy at $400 \times$ magnification using an image analysis system (Comet Assay II-Perceptive Instruments, Suffolk, UK). For each rat, 300 cells, i.e., 100 randomly selected cells (50 from each of two replicate slides) from each treatment (FPG, Endo III or enzyme buffer only), were evaluated 100 randomly selected cells (50 from each of two replicate slides) for each treatment (FPG, Endo III or enzyme buffer only) were evaluated and the mean tail intensity was determined. Tail intensity according to Comet Assay II-Perceptive Instruments is defined as "the sum of all intensity values in the tail region less those which are part of the mirrored head region. The value is also expressed as a percentage of the total Comet or cell intensity" [34].

\section{Evaluation of serum cotinine}

Serum cotinine levels were evaluated by ELISA according to the manufacturer's instructions (Sigma-Aldrich, St. Louis, MO, USA; product \#SE120083). The sensitivity of the ELISA kit was $1 \mathrm{ng} / \mathrm{ml}$.

\section{Statistical analysis}

Comparisons between groups were made by Student's $t$ test for parameters with normal distribution. Otherwise, comparisons between groups were made using the Mann-Whitney U test. Data were expressed as the mean \pm SD or medians (including the lower quartile and upper quartile). Data analysis was carried out with SigmaStat for Windows v2.03 (SPSS Inc., Chicago, IL). The significance level was considered $5 \%$.

\section{Results}

Serum cotinine levels, as expected, were elevated in the ETS group $[\mathrm{C}=0(0-0) \mathrm{ng} / \mathrm{ml}$ and $\mathrm{ETS}=2.52(1.80-$ $3.10) \mathrm{ng} / \mathrm{ml}, p=0.008]$. This result confirms the efficacy of the procedure for exposing animals to cigarette smoke. Isolated heart study data are shown in Table 1. There were no differences in systolic or diastolic functions between the groups.

Morphological data are summarized in Table 1. LV and lung weights corrected by body weight (BW) were higher in the ETS group compared with the $\mathrm{C}$ group. In addition, the myocyte cross-sectional area (CSA) was higher in the ETS group. $\left(C=266.6 \pm 23.2 \mu \mathrm{m}^{2}\right.$ and ETS $=347.5 \pm 15.1 \mu \mathrm{m}^{2}, p<0.001$ ) (Fig. 1).

The protein carbonyl and LH concentrations are shown in Table 2. The cardiac lipid hydroperoxide was higher in the ETS group compared with group C. However, there was no difference in protein carbonyl concentration between groups. In comet assays, including assays where FPG or endo III were added, there were no differences between groups in the mean tail intensities. (Table 3) (Fig. 2).

\section{Discussion}

The objective of our study was to analyze the different products of oxidative stress derived by smoking-induced damage to proteins, lipids and DNA in the remodeled heart. The primary finding of our study is that lipid damage is a good marker of cardiac oxidative damage in

Table 2 Cardiac determination of protein carbonyl, lipid hydroperoxide and antioxidant enzyme system

\begin{tabular}{llll}
\hline & C Group & ETS Group & \\
& $n=8$ & $n=8$ & $P$ value \\
\hline Protein carbonyl (nmol/mg of protein) & $2.52(1.70-3.18)$ & $3.10(3.07-3.14)$ & 0.310 \\
$\mathrm{LH}(\mathrm{nmol} / \mathrm{g})$ & $196.4 \pm 51.5$ & $331.9 \pm 52.9$ & $<0.001$ \\
\hline
\end{tabular}

$C$ control animals, ETS animals exposed to tobacco smoke, $L H$ lipid hydroperoxide

Data are expressed as the mean \pm SD or medians (including the lower quartile and upper quartile) 
Table 3 Comet assay

\begin{tabular}{llll}
\hline Tail intensity (\%) & $\begin{array}{l}\text { C Group } \\
n=6\end{array}$ & $\begin{array}{l}\text { ETS Group } \\
n=6\end{array}$ & P value \\
\hline Cardiac Tissue & & & \\
$\quad$ Buffer & $24.0 \pm 10.6$ & $18.9 \pm 6.4$ & 0.684 \\
FPG & $9.4 \pm 4.8$ & $10.4 \pm 7.1$ & 0.828 \\
Endo III & $6.6(6.2-12.5)$ & $5.4(4.8-14.2)$ & 0.400 \\
Blood & $22.5 \pm 3.3$ & $25.9 \pm 8.4$ & 0.485
\end{tabular}

C control animals, ETS animals exposed to tobacco smoke, FPG formamidopyrimidine glycosylase, Endo III endonuclease III

Data are expressed as the mean \pm SD or medians (including the lower quartile and upper quartile)

this model of tobacco smoke exposure. At least, after 2 months of tobacco smoke exposure, there were no differences in markers of protein or DNA damage.

Tobacco smoke can lead to cardiovascular diseases due to its effects on the vascular system and direct effects on cardiac remodeling and function [2-7]. Several studies have shown that ETS induces myocardial hypertrophy and ventricular dysfunction [2-9]. In our study, as expected, ETS induced myocyte hypertrophy, a hallmark of the cardiac remodeling process. Isolated hearts from animals exposed to tobacco smoke did not differ from hearts isolated from unexposed controls. In contrast, diastolic and systolic dysfunction were observed when cardiac function was assessed by echocardiogram [2-6]. It is important to note that preload, afterload and heart rate were controlled in our isolated heart model. Therefore, isolated heart preparation permits the analysis of cardiac function without interference of confounding variables, such as neurohormonal and hemodynamic factors. In this model, ETS induced hemodynamic alterations [35, 36]. Additionally, the cardiac remodeling and increased blood pressure induced by ETS were attenuated by lisinopril or propranolol $[35,36]$. Therefore, the contradictory results of the in vivo and in vitro functional analyses reinforce the importance of neurohormonal/hemodynamic changes in the remodeling process induced by ETS.

In addition to neurohormonal changes, tobacco smoke also induces cardiac and systemic oxidative stress. In fact, previous studies have suggested that ETS increases NADPH oxidase activity and affects mitochondrial respiration, increasing ROS formation [5, 6]. Rafacho et al. also showed that after two months of ETS there was a decrease in the cardiac activity of antioxidant enzymes and an increase in LH [5]. Notably, supplementation with pentoxifylline, retinoic acid and beta-carotene, substances with antioxidant properties, have been shown to attenuate the ventricular remodeling process induced by smoking [37-40]. However, despite all the evidence showing the major role of ETS in cardiac oxidative damage, no study, until now, has analyzed the participation of lipid peroxidation, protein oxidation and DNA damage as targets of oxidative stress induced by exposure to cigarette smoke in this model.

ROS causes oxidative damage to DNA, proteins and lipids, and some studies have shown different behaviors of these oxidative macromolecular products. The time of their measurement, tissue specificity and the nature of
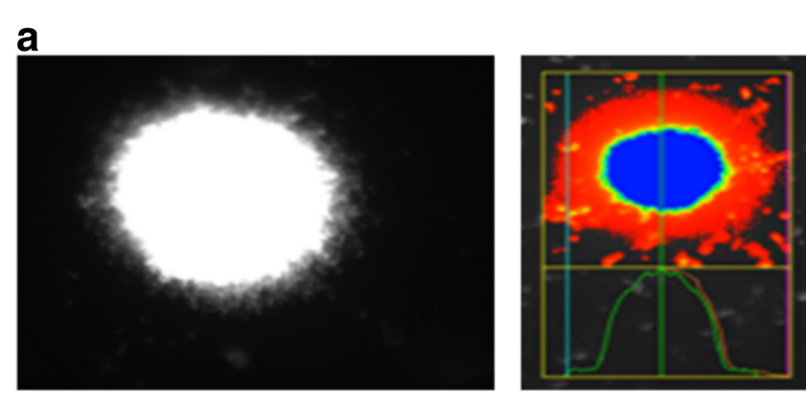

C

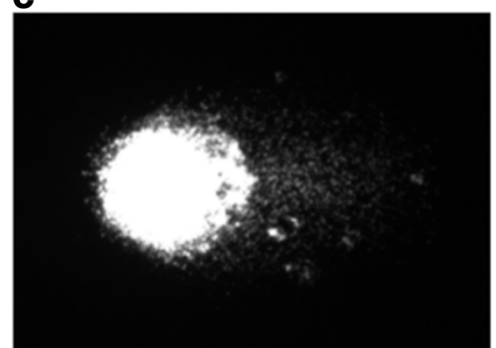

b
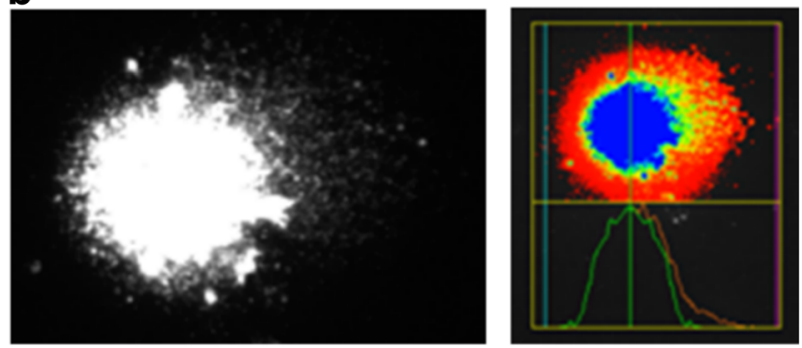

d

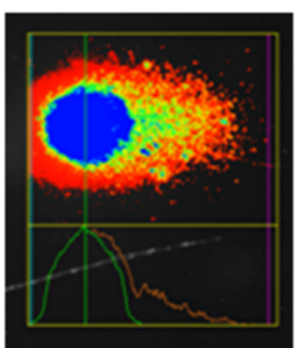

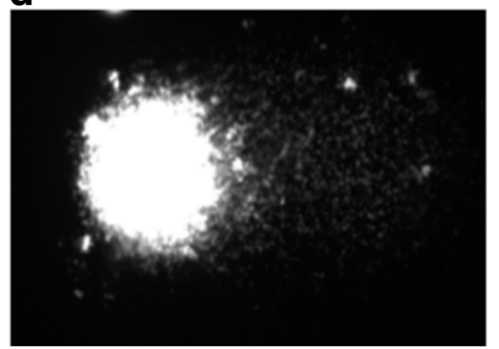

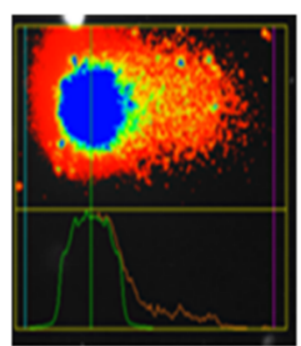

Fig. 2 Comet assay. a Tail intensity in cardiac tissue from the C group. b Tail intensity in cardiac tissue from the ETS group. c Tail intensity in blood from the $\mathbf{c}$ group $\mathbf{d}$. Tail intensity in blood from the ETS group. There were no differences between groups in the mean tail intensity in the blood or in the cardiac tissue 
ROS could explain these differences. It is well-known that protein carbonyl groups are formed early and are more stable than lipid peroxidation products, which are detoxified within minutes [24, 25]. Carbonyl groups have been analyzed as a biomarker of oxidative damage of proteins. Reznick et al. showed that in vitro exposure of plasma to cigarette smoke leads to rapid accumulation of protein carbonyl groups [41]. However, Yeh et al. showed that in 542 participants of the Early Lung Cancer Action Project carbonyl levels were not significantly different between current and former smokers and were not correlated with urine cotinine levels, pack-years or pack/day [19]. In our study, LV protein carbonyl concentrations did not differ between the control and ETS groups, assessed after two months of follow-up. This result suggests that at least at this time point, protein damage does not play a role in the cardiac remodeling induced by smoking.

Regarding DNA damage, several studies reported increased levels of 8-hydroxyguanine in smokers compared to nonsmokers [17-19]. However, conflicting results have been reported with comet assays to measure DNA damage related to ETS [20-22]. Hoffmann and Speit showed no significant difference in genotoxic effects in peripheral bloods cells between heavy smokers and nonsmokers [21]. In addition, an experimental study compared DNA damage in peripheral blood leukocytes from diabetic and non-diabetic female Wistar rats exposed to air or to cigarette smoke [20]. In this study, non-diabetic and diabetic rats exposed to cigarette smoke presented non-significant increases in DNA damage levels compared to the control group [20]. In our study, we evaluated peripheral blood leukocytes and cardiac tissue and we found no differences in comet tail intensities between the groups, even when the LV samples were exposed to FPG and endo III, which recognize oxidized purines and pyrimidines, respectively. Therefore, protein damage does not appear to participate in the chronic remodeling process in this model.

We should consider some limitations of our study. Firstly, we did not measure blood pressure and inflammatory mediators of the animals. In addition, we did not evaluate the lung tissue in this study.

Considering all of our results, we infer that LH was the only biomarker of oxidative stress that was increased in rats ETS. Therefore, at least following 2 months of ETS, we showed, by the first time, that lipid peroxidation seems more important than DNA or protein damage on cardiac remodeling induced by smoking.

\section{Conclusions}

In conclusion, our results suggest that, in this model, lipid damage is a good marker of oxidative damage during the cardiac remodeling process induced by 2 months of tobacco smoke exposure.

\section{Abbreviations}

$+\mathrm{dP} / \mathrm{dt}$ : Maximum left ventricular pressure development rate; AP: Apurinic/ apyrimidinic; BW: Body weigth; C: Control; CSA: Myocyte cross-sectional area; -dP/dt: The maximum left ventricular pressure decrease rate; ETS: Exposed to tobacco smoke; FPG: Formamidopyrimidine glycosylase; HE: Hematoxylin and eosin; LH: Lipid hydroperoxide; LV: Left ventricle; NADPH: Nicotinamide adenine dinucleotide phosphate; ROS: Reactive oxygen species; SBs: Labile sites

\section{Acknowledgements}

Not applicable.

\section{Funding}

This research was supported by the State of São Paulo Research Foundation (FAPESP - 2014/21310-0).

\section{Availability of data and materials}

The datasets used and/or analysed during the current study are available from the corresponding author on reasonable request.

\section{Authors' contributions}

MAML - acquisition, analysis and interpretation of data, drafting the article MGB, AGA, BLBP, FHF, EMK, TFB, PSA, BFP, SGZ, AAHF - acquisition, analysis and interpretation of data; LAMZ, SARP, MFM - study design, data interpretation, revising the manuscript. All authors revised the article critically for important intellectual content, and approved the final version of the manuscript.

\section{Ethics approval}

All experiments and procedures were performed in accordance with the National Institute of Health Guide for the Care and Use of Laboratory Animals and were approved by the Animal Ethics Committee of Botucatu Medical School.

Consent for publication

Not applicable.

\section{Competing interests}

The authors declare that they have no competing interests.

\section{Publisher's Note}

Springer Nature remains neutral with regard to jurisdictional claims in published maps and institutional affiliations.

\section{Author details}

${ }^{1}$ Internal Medicine Department, Botucatu Medical School, UNESP - São Paulo State University, Botucatu, Brazil. '2Department of Anesthesiology, Botucatu Medical School, UNESP - São Paulo State University, Botucatu, Brazil. ${ }^{3}$ Department of Genetics, Institute of Biological Sciences, UNESP - São Paulo State University, Botucatu, Brazil. ${ }^{4}$ Chemistry and Biochemistry Department, Institute of Biological Sciences, Botucatu Medical School, UNESP - São Paulo State University, Botucatu, Brazil. ${ }^{5}$ Departamento de Clínica Médica, Faculdade de Medicina de Botucatu, Rubião Júnior s/n, Botucatu, SP CEP: 18618-000, Brazil.

Received: 30 November 2017 Accepted: 2 November 2018 Published online: 16 November 2018

\section{References}

1. Jamal A, King BA, Neff LJ, Whitmill J, Babb SD, Graffunder CM. Current cigarette smoking among adults - United States, 2005-2015. MMWR Morb Mortal Wkly Rep. 2016:65:1205-11.

2. Castardeli E, Paiva SA, Matsubara BB, Matsubara LS, Minicucci MF, Azevedo PS, et al. Chronic cigarette smoke exposure results in cardiac remodeling and impaired ventricular function in rats. Arq Bras Cardiol. 2005;84:320-4.

3. Castardeli E, Duarte DR, Minicucci MF, Azevedo PS, Matsubara BB, Matsubara LS, et al. Tobacco smoke-induced left ventricular remodelling is not 
associated with metalloproteinase-2 or -9 activation. Eur J Heart Fail. 2007; 9:1081-5.

4. Zornoff LA, Matsubara LS, Matsubara BB, Okoshi MP, Okoshi K, Dal Pai-Silva $M$, et al. Beta-carotene supplementation attenuates cardiac remodeling induced by one-month tobacco-smoke exposure in rats. Toxicol Sci. 2006; 90:259-66.

5. Rafacho BP, Azevedo PS, Polegato BF, Fernandes AA, Bertoline MA, Fernandes DC, et al. Tobacco smoke induces ventricular remodeling associated with an increase in NADPH oxidase activity. Cell Physiol Biochem. 2011;27:305-12.

6. Santos PP, Oliveira F, Ferreira VC, Polegato BF, Roscani MG, Fernandes AA, et al. The role of lipotoxicity in smoke cardiomyopathy. PLoS One. 2014;9: e113739.

7. Gu L, Pandey V, Geenen DL, Chowdhury SAK, Piano MR. Cigarette smokeinduced left ventricular remodelling is associated with activation of mitogen-activated protein kinases. Eur J Heart Fail. 2008;10:1057-64.

8. Fidelix MP, Tanni SE, Roscani MG, Mesquita CB, Schelini KNM, Polegato BF, et al. Vitamin D role in smoking women and cardiac remodeling. Nutrire. 2016;41:13.

9. Brooks WW, Bing $\mathrm{OH}$, Huber GL, Abermann WH. Contractile performance of rat myocardium after chronic tobacco smoke inhalation. Arch Environ Heath. 1982;37:93-7.

10. Tanus-Santos JE, Sampaio RC, Hyslop S, Franchini KG, Moreno H Jr. Endothelin ET(a) receptor antagonism attenuates the pressor effects of nicotine in rats. Eur J Pharmacol. 2000;396:33-7.

11. Duarte DR, Minicucci MF, Azevedo PS, Matsubara BB, Matsubara LS, Novell $E L$, et al. The role of oxidative stress and lipid peroxidation in ventricular remodeling induced by tobacco smoke exposure after myocardial infarction. Clinics. 2009;64:691-7.

12. Kaplan A, Abidi E, Ghali R, Booz GW, Kobeissy F, Zouein FA. Functional cellular, and molecular remodeling of the heart under influence of oxidative cigarette tobacco smoke. Oxidative Med Cell Longev. 2017;2017:3759186.

13. Minicucci MF, Azevedo PS, Polegato BF, Paiva SA, Zornoff LA. Cardiac remodeling induced by smoking: concepts, relevance, and potential mechanisms. Inflamm Allergy Drug Targets. 2015;14:125-32.

14. Yao H, Edirisinghe I, Yang S, Rajendrasozhan S, Kode A, Caito S, et al. Genetic ablation of NADPH oxidase enhances susceptibility to cigarette smoke-induced lung inflammation and emphysema in mice. Am J Pathol. 2008;172:1222-37.

15. Fernandes DC, Wosniak J Jr, Pescatore LA. Analysis of DHE-derived oxidation products by HPLC in the assessment of superoxide production and NADPH oxidase activity in vascular systems. Am J Physiol Cell Physiol. 2007;292: C413-22.

16. Tsutsui H, Kinugawa S, Matsushima S. Oxidative stress and heart failure. Am J Physiol Heart Circ Physiol. 2011;301:H2181-90.

17. Kiyosawa H, Suko M, Okudaira H, Murata K, Miyamoto T, Chung MH, et al. Cigarette smoking induces formation of 8-hydroxydeoxyguanosine, one of the oxidative DNA damages in human peripheral leukocytes. Free Radic Res Commun. 1990;11:23-7.

18. Loft S, Vistisen K, Ewertz M, Tjonneland A, Overvad K, Poulsen HE. Oxidative DNA damage estimated by 8-hydroxydeoxyguanosine excretion in humans: influence of smoking, gender and body mass index. Carcinogenesis. 1992; 13:2241-7.

19. Yeh CC, Barr RG, Powell CA, Mesia-Vela S, Wang Y, Hamade NK, et al. No effect of cigarette smoking dose on oxidized plasma proteins. Environ Res. 2008;106:219-25.

20. Lima PH, Sinzato YK, de Souza Mda S, Braz MG, Rudge MV. Damasceno DC Evaluation of level of DNA damage in blood leukocytes of non-diabetic and diabetic rat exposed to cigarette smoke. Mutat Res. 2007;628:117-22.

21. Hoffmann H, Speit G. Assessment of DNA damage in peripheral blood of heavy smokers with the comet assay and the micronucleus test. Mutat Res. 2005:581:105-14.

22. Braz MG, Salvadori DM. Lack of genotoxicity induced by endogenous and synthetic female sex hormones in peripheral blood cells detected by alkaline comet assay. Environ Mol Mutagen. 2007;48:414-20.

23. Dalle-Donne I, Colombo G, Gornati R, Garavaglia ML, Portinaro N, Giustarin D, et al. Protein Carbonylation in Human Smokers and Mammalian Models of Exposure to Cigarette Smoke: Focus on Redox Proteomic Studies. Antioxid Redox Signal. 2017;26:406-26.

24. Dalle-Donne I, Rossi R, Giustarini D, Milzani A, Colombo R. Protein carbonyl groups as biomarkers of oxidative stress. Clin Chim Acta. 2003;329:23-38.
25. Andresen M, Regueira T, Bruhn A, Perez D, Strobel P, Dougnac A, et al Lipoperoxidation and protein oxidative damage exhibit different kinetics during septic shock. Mediat Inflamm. 2008;2008:168652.

26. Wang X-D, Liu C, Bronson RT, Smith DE, Krinsky NI, Russel RM. Retinoid signaling and activator protein-1 expression in ferrets given b-carotene supplements and exposure to tobacco smoke. J Natl Cancer Inst. 1999;91: 60-6.

27. Polegato BF, Minicucci MF, Azevedo PS, Carvalho RF, Chiuso-Minicucci F, Pereira EJ, et al. Acute doxorubicin-induced cardiotoxicity is associated with matrix metalloproteinase-2 alterations in rats. Cell Physiol Biochem. 2015;35: 1924-33.

28. Burneiko RCM, Diniz YS, Galhardi CM, Okoshi K, Matsubara LS, Matsubara BB et al. Interaction of hypercaloric diet and physical exercise on lipid profile, oxidative stress and antioxidant defenses. Food Chem Toxicol. 2006;44: 1167-72.

29. Nakamura W, Hosoda S, Hayashi K. Purification and properties of rat liver glutathione peroxidase. Biochem Biophys Acta. 1974;358:251-61.

30. Ewing JF, Janero DR. Microplate superoxide dismutase assay employing a nonenzimatic superoxide generator. Anal Biochem. 1995;232:243-8.

31. Reznick AZ, Packer L. Oxidative damage to proteins: spectrophotometric method for carbonyl assay. Methods Enzymol. 1994;233:357-63.

32. Pool-Zobel BL, Lotzmann N, Knoll M, Kuchenmeister F, Lambertz R, Leuch $U$, et al. Detection of genotoxic effects in human gastric and nasal mucosa cells isolated from biopsy samples. Environ Mol Mutagen. 1994;24:23-45.

33. Strauss GHS. Non-random cell killing in cryopreservation: implications for the performance of the battery of leukocyte tests (BLT) I. toxic and imunotoxic effects. Mutat Res. 1991;252:1-15.

34. Ferreira AL, Salvadori DM, Nascimento MC, Rocha NS, Correa CR, Pereira EJ, et al. Tomato-oleoresin supplement prevents doxorubicin-induced cardiac myocyte oxidative DNA damage in rats. Mutat Res. 2007;631:26-35.

35. Duarte DR, Minicucci MF, Azevedo PS, Chiuso-Minicucci F, Matsubara BB, Matsubara LS, et al. Influence of lisinopril on cardiac remodeling induced by tobacco smoke exposure. Med Sci Monit. 2010;16:BR255-9.

36. Duarte DR, Oliveira LC, Minicucci MF, Azevedo PS, Matsubara BB, Matsubara $L S$, et al. Effects of the administration of beta-blockers on ventricular remodeling induced by cigarette smoking in rats. Arq Bras Cardiol. 2009;92: 443-7.

37. Minicucci M, Oliveira F, Santos P, Polegato B, Roscani M, Fernandes AA, et al Pentoxifylline attenuates cardiac remodeling induced by tobacco smoke exposure. Arq Bras Cardiol. 2016;106:396-403.

38. Rafacho BP, Santos P, Assalin HB, Ardisson LP, Roscani MG, Polegato BF, et al. Role of vitamin $D$ in the cardiac remodeling induced by tobacco smoke exposure. Int J Cardiol. 2012;155:472-3.

39. Oliveira LC, Azevedo PS, Minicucci MF, Rafacho BP, Duarte DR, Matsubara LS, et al. Retinoic acid prevents ventricular remodelling induced by tobacco smoke exposure in rats. Acta Cardiol. 2011;66:3-7.

40. Zornoff LA, Duarte DR, Minicucci MF, Azevedo PS, Matsubara BB, Matsubara LS, et al. Effects of beta-carotene and smoking on heart remodeling after myocardial infarction. Arq Bras Cardiol. 2007;89:135-41.

41. Reznick AZ, Cross CE, Hu ML, Suzuki YJ, Khwaja S, Safadi A, et al. Modification of plasma proteins by cigarette smoke as measured by protein carbonyl formation. Biochem J. 1992;286:607-11.

Ready to submit your research? Choose BMC and benefit from:

- fast, convenient online submission

- thorough peer review by experienced researchers in your field

- rapid publication on acceptance

- support for research data, including large and complex data types

- gold Open Access which fosters wider collaboration and increased citations

- maximum visibility for your research: over $100 \mathrm{M}$ website views per year

At BMC, research is always in progress.

Learn more biomedcentral.com/submission 